\title{
Cine interleaved sequences enabled imaging of mice on clinical 3T MRI and analysis of their cardiac function after myocardial infarction
}

\author{
Alexandre Belin ${ }^{1,2^{*}}$, Vincent Braunersreuther ${ }^{1,2}$, Fabrizio Montecucco ${ }^{1,2}$, Benedicte M Delattre ${ }^{1,2}$, Francois Mach $^{1,2}$, \\ Jean Vallee ${ }^{1,2}$
}

From 15th Annual SCMR Scientific Sessions

Orlando, FL, USA. 2-5 February 2012

\section{Background}

With the poor availability of small animal dedicated MRI, it is of great interest and challenge to use clinical MRI to image and analyze the cardiac function of mice. This would of course be advantageous for translational research and also enable the use of up-to-date sequences already implemented in clinical routine. The aim is to study the time evolution of cardiac function in mice with a myocardial infarct on a clinical MRI.

\section{Methods}

C57BL/6 mice ( $\mathrm{n}=4)$ were submitted in vivo to left coronary artery permanent ligature and compared and with compared with non-operated mice $(n=4)$. The mice were imaged on a clinical Siemens 3T MRI using an "interleaved" sequence constructed from an ECG-triggered turboflash cine sequence, combining two acquisitions shifted in time yielding an effective time resolution of $6.8 \mathrm{~ms}$ and 20-26 phases per heart beat with following parameters: FOV $111 \mathrm{~mm}$, in-plane resolution 257 $\mu \mathrm{m}$, slice thickness $1 \mathrm{~mm}$, TE/TR 6.2/13.5 ms, flip angle $30^{\circ}$. A soft-thresholding of the temporal Fourier coefficients was used to further denoise the images. The mice were scanned at $24 \mathrm{~h}$ and 22 days after coronary ligation.

\section{Results}

High quality images suitable for endocardial contouring were obtained for all the animals. The systolic and diastolic volumes, as well as the ejection fraction, are reported in Table 1 . The anterior wall of all the operated animals was akenetic as shown on Figure 1. The

Radiology, HUG, Geneve 14, Switzerland

Full list of author information is available at the end of the article ejection fraction was significantly decreased in the infarcted group at $24 \mathrm{~h}$ and 22 days by comparison to the control group $(p=0.006$ and $p=0.003)$. There was also a trend for the global function to decrease from $24 \mathrm{~h}$ to 22 days.

Table 1 Cardiac properties of the mice

\begin{tabular}{|c|c|c|c|}
\hline & ESV (ul) & EDV (ul) & $\mathrm{EF}$ \\
\hline \multicolumn{4}{|l|}{ INF 24h } \\
\hline EVAMR135 & 65.26 & 88.12 & 0.26 \\
\hline EVAMR90 & 51.27 & 69.73 & 0.26 \\
\hline EVAMR174 & 43.66 & 70.13 & 0.38 \\
\hline EVAMR175 & 51.27 & 81.90 & 0.37 \\
\hline MEAN & 52.87 & 77.47 & 0.32 \\
\hline SD & 9.01 & 9.07 & 0.07 \\
\hline \multicolumn{4}{|l|}{ INF 22j } \\
\hline EVAMR135 & 289.57 & 356.57 & 0.19 \\
\hline EVAMR90 & 208.26 & 241.62 & 0.14 \\
\hline EVAMR174 & 61.75 & 91.41 & 0.32 \\
\hline EVAMR175 & 66.65 & 109.09 & 0.39 \\
\hline MEAN & 156.56 & 199.67 & 0.26 \\
\hline SD & 111.71 & 124.23 & 0.12 \\
\hline \multicolumn{4}{|l|}{ NON INF } \\
\hline P1 & 21.13 & 56.86 & 0.63 \\
\hline P2 & 33.92 & 69.12 & 0.51 \\
\hline P3 & 36.83 & 79.46 & 0.54 \\
\hline P4 & 47.59 & 90.64 & 0.47 \\
\hline MEAN & 34.87 & 74.02 & 0.54 \\
\hline SD & 10.88 & 14.43 & 0.07 \\
\hline
\end{tabular}

(c) 2012 Belin et al; licensee BioMed Central Ltd. This is an open access article distributed under the terms of the Creative Commons 


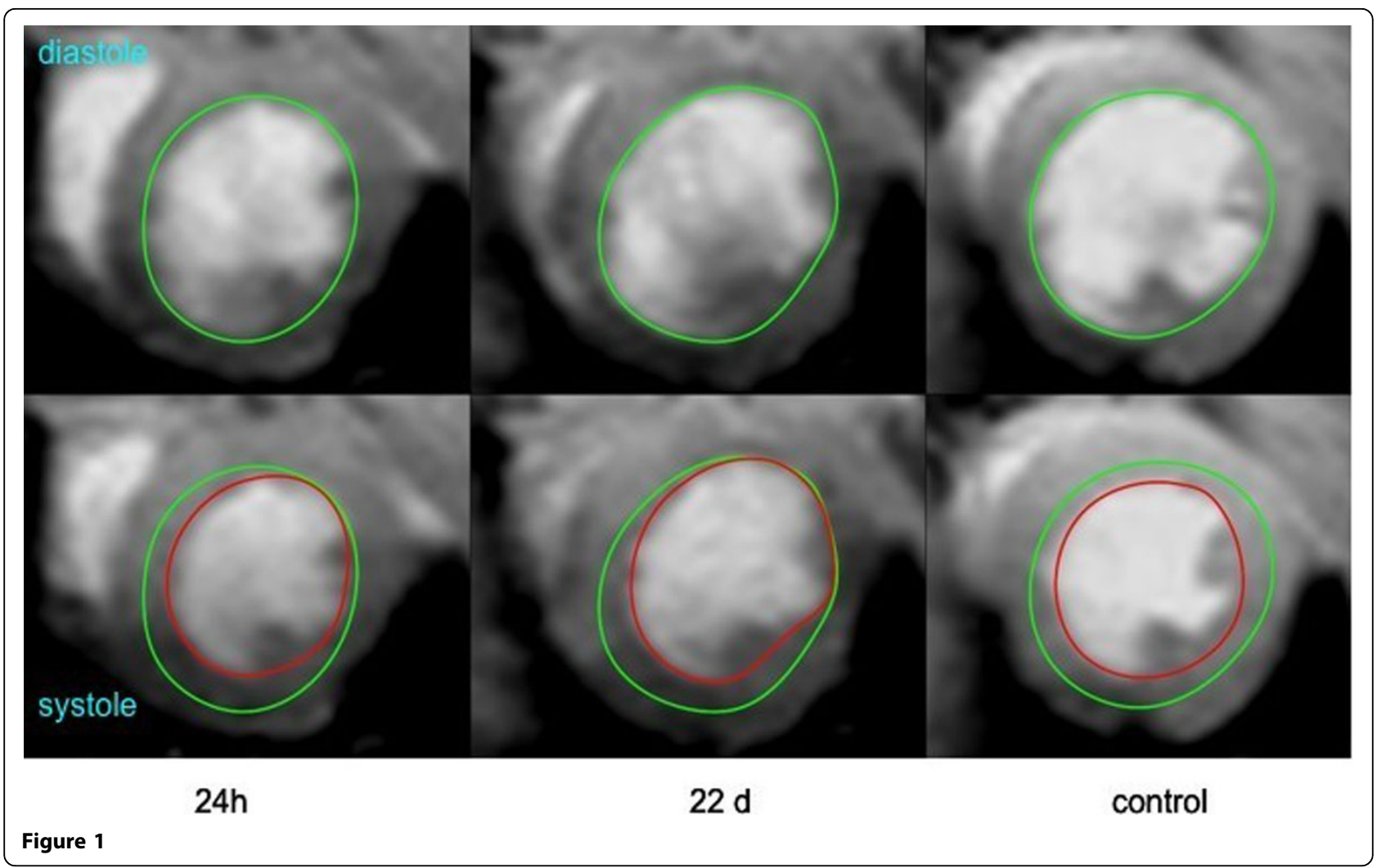

\section{Conclusions}

We demonstrated a robust protocol to study cardiac functions in mice with a myocardial infarct using a clinical 3T MRI. This methodology has a strong potential to study the effect of treatment in rodents.

\section{Funding}

This work was partially supported by the Swiss National Science Foundation (grant PP00P2-123438).

\section{Author details}

${ }^{1}$ Radiology, HUG, Geneve 14, Switzerland. ${ }^{2}$ Faculty of medicine, University of

Geneva, Geneva, Switzerland.

Published: 1 February 2012

doi:10.1186/1532-429X-14-S1-P60

Cite this article as: Belin et al:: Cine interleaved sequences enabled imaging of mice on clinical 3T MRI and analysis of their cardiac

function after myocardial infarction. Journal of Cardiovascular Magnetic Resonance 2012 14(Suppl 1):P60.

\section{Submit your next manuscript to BioMed Central} and take full advantage of:

- Convenient online submission

- Thorough peer review

- No space constraints or color figure charges

- Immediate publication on acceptance

- Inclusion in PubMed, CAS, Scopus and Google Scholar

- Research which is freely available for redistribution 